\title{
“GIME, BANDONEÓN”. APROXIMACIONES AL TANGO Y SUS NARRATIVAS
}

\author{
PABLO GÓMEZ ASCENCIO ${ }^{14}$ \\ Universidad Nacional Autónoma de México \\ ORIENTE 249 D \# 173, Col. Agrícola Oriental, Iztacalco, C.P. 08500, México D.F. \\ gargolea@gmail.com
}

\section{RESUMEN}

Este trabajo constituye un esbozo de un planteamiento sobre elementos generales de la narrativa exiliar del tango. Para ello, se estima parte de la historia del género; así como la comparativa dicotómica de las nociones de insilio, exilio y sus definiciones en distintas fuentes. La línea de esta aproximación desarrolla el análisis de tres casos específicos de hechos vinculados al tango -diferenciados de manera genérica en música, literatura y cine. En estos se acentúan las particularidades, a través de una aproximación metodológica libre sobre los mediadores que inciden en la concreción de los hechos.

Palabras clave: Sociología de la música, música popular, tango, exilio.

"GROANS, BANDONEON". APPROXIMATIONS TO THE TANGO AND HIS NARRATIVES

\section{ABSTRACT}

This work constitutes a sketch of an exposition on general elements of the exiling narrative of tango. To that end, part of the history of the genre is estimated, as well as the dichotomous comparative of the notions of inner exile, exile and its definitions in different sources. The line of this approach develops the analysis of three specific cases of facts linked to tango - differentiated in a generic way in

\footnotetext{
${ }^{14}$ Licenciado en Sociología, por la Universidad Nacional Autónoma de México. Asistente de la Dra. Ana Garduño en el Centro Nacional de Investigación, Documentación e Información de Artes Plásticas (CENIDIAP) y del Dr. Peter Krieger del Instituto de Investigaciones Estéticas, UNAM. Integrante del Seminario "Identidades, cambio social e interculturalidad" del Centro de Investigaciones sobre América Latina y el Caribe, UNAM.
} 
music, literature and cinema. In these, peculiarities accentuated through a methodological free approach on the mediators that affect the concretion of the facts.

Key words: Sociology of music, popular music, tango, exilio.

\section{Introducción}

Usualmente estos ejercicios comienzan con un designio articulante del peso de un fenómeno complejo. El tango, en este caso. Sin embargo, definir implica descolocar al objeto del presente y situar en un sustrato anacrónico un hecho que nunca termina de conformarse. Por ello, no se buscó disponer una trama de conjeturas fijas sobre un fenómeno intrincado, sino detallar parte de un esfuerzo analítico por recopilar fuentes, testimonios y materiales del género en México. Como primera consecuencia devino la hipótesis que sustenta este trabajo, que es: el tango, imbuido de un complejo sistema de significados y narrativas, preserva y expresa de forma continua, a lo largo de su desarrollo, el motivo dicotómico exilio/insilio, ya presente desde sus orígenes mismos.

De esta manera, se parte de un acercamiento breve -en la medida de lo posible-, al origen y desarrollo del tango, a través del cual se caracterizaron diversos mediadores de una narrativa en la que se integran estereotipos y valores que se reproducen. Después, se identificó parte de esta narrativa en tres productos vinculados con el tango: la película El exilio de Gardel de Fernando Pino Solanas, el cuento El fuelle infinito de Gabriel Schutz y el disco Tangos de Eugenia León. Todos ellos como pruebas -disímiles y manifiestas a la vez-, de la dicotomía exilio/insilio como parte fundamental que constituye la narrativa mitológica del género.

\section{Categorías de la separación: exilio e insilio}

Propiamente, la característica que define al exilio de otros procesos teñidos de tránsito y desplazamiento. Es la obligatoriedad externa que determina el desarraigo del individuo y que propicia además una crisis de la propia identidad personal y del entorno con el cual se identifica. El exilio implica entonces el despojo de una realidad geográfica y de la propia identidad; es la violencia de 
perder la condición de una cotidianidad íntima por una descolocamiento forzoso ante diversas razones: las creencias religiosas, el pensamiento político, los sistemas de costumbres y las necesidades económicas.

De forma complementaria a la condición de exilio, existe otra caracterización: el exilio interior o insilio -neologismo de autoría reñida ${ }^{15}$. Esta se refiere a un proceso de alienación consciente o de marginación, sufrida por quienes no necesariamente cargan el exilio, pero sí una discrepancia respecto a su realidad personal y al contexto que les rodea. Más allá de la paronimia entre exilio e insilio, ambos conceptos comparten el sentido del desarraigo impuesto por un agente externo.

Ahora bien, según la conceptualización del insilio esta es amplia en la dimensión de su interioridad; contiene un peso metafórico bastante flexible. De esta manera, si bien el insilio se aplica de manera usual a la permanencia en un lugar, pero con una falta de identificación respecto a una presente violentada que se percibe en dicho entorno, es posible que un exiliado pueda ser al mismo tiempo insiliado. Ello según le sea ajeno el nuevo lugar en el que es obligado a radicar, por lo que ya no es un espacio cotidiano en sí mismo, sino un medio transitorio. En todo caso, el exilio o el insilio refieren a una realidad de la cual fue despojado el sujeto $^{16}$.

Del mismo modo, en tanto el exilio puede significar una mera asignación demográfica de la movilidad forzada; también se hace una consideración más amplia del término. Así, puede abarcar otros elementos constitutivos de la cotidianidad, como la experiencia del discurso y la disolución del sentido del lenguaje; hecho que en la medida del despojo implica en un desenlace encaminado a la pérdida de un contexto.

Igualmente, es importante resaltar que la dualidad exilio/insilio es puesta en escena mediante la concientización y la memoria histórica sobre aquellos procesos más actuales que ejercieron acciones de alejamiento sobre los

\footnotetext{
${ }^{15}$ Nélida Ricceto (1993) lo atribuye a Mario Benedetti. Perelli (1986) señala a Diego Perez Pintos. Chase (1995) a Mauricio Rosencof.

${ }^{16}$ Lo que para Berger y Luckmann (2006), devendría del enrarecimiento de una realidad subjetiva cuyos procesos de institucionalización consuetudinarios son puestos en entredicho.
} 
individuos, tales como los regímenes militares. De forma operativa, extiendo aquí su uso como una variable analítica aplicada a las olas migratorias europeas que arribaron a Uruguay y Argentina, de las que se conservan testimonios identitarios, más bien costumbristas. De tal manera que no permiten reconstruir -a diferencia de los desarraigos más actuales- modelos propios que argumentan procesos exiliares, pero que de acuerdo con las consideraciones antes planteadas, caben dentro de dichas categorías.

Evidentemente, hay bastantes matices de por medio en las acepciones que se otorgan en este trabajo al exilio y el insilio, por lo que se reitera que la apertura de la que se hace uso está dirigida al contexto específico de los hechos, no a una norma axiológica inoperante.

\section{El tango es hijo de la milong $a^{17}$}

Con un proceso de formación que se extiende largos años y que abarca diversos linajes, el tango hace su aparición formal en la segunda mitad del s. XIX, a orillas del Río de la Plata; en Uruguay y Argentina, países que disputan su autoría, -ya con más reconocimiento mutuo que con auténtica polémica-. Lo dijo el poeta Horacio Ferrer (1979), personaje íntimo al submundo tanguero: "Su gestación se parece un poco al amasijo y otro poco al embarazo" (p.XVII). Es precisamente el crisol de una de perplejidad que reconcilia lo incompatible el contexto de su origen: se sitúa entre la independencia política de España y las pugnas sociales por la descolonialización cultural y económica, encaminadas a la construcción de dos naciones.

Así, como parte de este proceso de construcción nacional, durante la segunda mitad del s. XIX surge, tanto en Argentina como en Uruguay, un proyecto civilizatorio destinado a favorecer la migración internacional. Este con el supuesto que las masas de inmigrantes favorecerían, con el arribo de sus familias, técnicas y herramientas de trabajo; al fin y al cabo el desarrollo de un anhelado progreso que emulara una idealización eurocéntrica. Junto a este proyecto, comienza

\footnotetext{
${ }^{17}$ Refiere a una declaración de Alfredo Zitarrosa: "La milonga es hija del candombe, así como el tango es hijo de la milonga..." Un sample de la frase -con la voz del músico- aparece en (Bajofondo Tango Club, 2007).
} 
también a incrementar la migración interna, en su mayoría de habitantes del medio rural atraídos por las condiciones de la ciudad. La idealización de este proyecto fracasa, y los inmigrantes que no tienen los medios de regresar a sus lugares de origen, se concentran en las orillas de las ciudades o en penosos asentamientos rurales.

Una burla que data 1903, es por demás reveladora del fracaso de los designios originales del plan: "Vengo por inmigrantes; pero desde hoy me los tiene usted que dar tamizados porque no quiero que haya agitadores, revolucionarios, huelguistas, comunistas, socialistas, anarquista" (Sabato, 1997, p.83). Empero, la ruina del proyecto civilizador y la disposición de los inmigrantes como foco del desprecio de los criollos -quienes genéricamente corresponden a los sectores urbanos que no eran descendientes ni parte de los expatriados- afianzó el terreno para el desarrollo del tango, cuyos anónimos artífices fueron, de manera esencial, los desterrados. El testimonio más fecundo sobre este aporte se halla en dos hechos: el primero es la imprecisa variedad instrumental que conforma los primeros ensambles del tango: la flauta, la guitarra, el violín y algún otro instrumento que salía al paso; el segundo, los pulsos que determinaron los ritmos de sus embates.

Así, el tango le debe parte de su identidad a la habanera, a la contradanza, a la tarantela, al tiento y al vals. Todos ellos son mal memorizados y peor tocados por músicos entonados para el alcohol, en calles mal iluminadas y prostíbulos atiborrados de melancolía y desarraigo.

Entre la convivencia de los géneros y la indiferencia de los tañedores, pronto estos bailes combinaron sus pulsos y devinieron en formas compuestas ya no reconocibles de las que les dieron cauce. Pero productos del mestizaje y destinados a una común identidad difusa que adquiere nombre y forma en dos bailes: el candombe y la milonga; alegres modos definidos por la procacidad de sus letras y la provocación de la danza. Estos son factores comunes del tango primigenio, en el que combatía con guitarras y cuchillos grupos de personajes enlazados al mito, la idealización y el duelo: los gauchos -especie de 
jinetes/campesinos-, así como los guapos y sus imitadores, los compadritos y malevos.

De este grupo, los primeros eran pendencieros que presumían en su cuerpo las marcas de peleas en las que se arriesgaba más el honor que la vida. Los otros, eran burdos imitadores del coraje de los peleadores. Sin embargo, todos ellos convivían en los tablados para demostrar sus destrezas en el tango primitivo, a la vez que compartían un lenguaje críptico derivado de los diversos cruces y préstamos lingüísticos entre expatriados. Esta jerga encaminada a guardar el sentido del arrabal y las intenciones del bajo fondo, pronto recibió el apelativo de lunfardo, sustantivo que originalmente referenciaba a los ladrones y malevos. Este término se extendió a este dialecto mixto, pleno de significantes y juegos retóricos que terminaron por nutrir las letras de los tanguitos que al paso nacieron. Con ello, el exilio que también que precisa definiciones y sistemas de silencios propios, encontró arraigo lingüístico en el tango.

Los vecinos, hijos y cómplices de los inmigrantes fueron los herederos de este ambiente de arrabales y de ellos surgirían los músicos que llegarían a ser caracterizados como los primeros compositores formales de tangos, quienes integraron la denominada Guardia Vieja. Ellos contribuyeron a la conformación de un estilo musical más lento y depurado que las desordenadas bullas arrabaleras, las que se privilegiaba el sentido melódico de una agrupación precisa integrada por el violín, el piano y el bandoneón en lugar de una guitarra destemplada y una armónica vieja. También surgió una progresiva racionalización de la danza en detrimento de la antigua tosquedad de los candombes y milongas ${ }^{18}$.

Cronológicamente, esta historia se sitúa ya hacia 1900 en el auge de los interrogantes nacionalistas y el tango, con la carga de un primitivismo popular, es dispuesto en Europa como novedad. En París se nutre entonces de la apariencia y el cosmopolitismo, razones por las que sublima su aparente exotismo en favor de reconsiderarlo como un producto admisible del mestizaje (cfr. Garramuño, 2007,

\footnotetext{
${ }^{18}$ La racionalidad es un concepto de Max Weber y se aplica al desarrollo de elementos institucionales y de estandarización propias del ethos de sociedades basadas en la identificación de medios/fines precisos. Un uso bastante detallado sobre la racionalización aplicada a la danza se encuentra en: (Gastón, 2008).
} 
pp.45-78). Un tango de la época reza: "Te cambiaron de pinta allá en Europa / y en francés te llamaron 'le tangó', / pero vos no cambiaste con la ropa / y seguís siendo reo igual que yo" (Sabato, 1997, p.113).

De este modo, el tango ya no es solo un fenómeno cultural de los desposeídos, sino también un producto que responde adecuadamente a la búsqueda de elementos que integren la trama cultural de los proyectos de nación; Las vanguardias literarias se nutren de las mismas fuentes que sus antecesores desatendieron y se concibe incluso como materia prima cultural de exportación. Además, adquiere la dimensión institucional adecuada para conformar una tradición capaz de fundamentar estereotipos genéricos y mitologías.

Los compadritos y los gauchos, personajes en proceso de extinción, se incorporan como fuente de idealización. La ciudad y sus antes imprecisos confines adquieren un aura de abstracta nostalgia y se fijan temas precisos a contar. Muestra de ello es el tango canción, género que surge con Mi noche triste, popularizado hacia 1917- y que configura a su vez un distanciamiento temático con los tangos criollistas, ocupados de la narrativa urbana y también con los tañedores que idealizaban el entorno de los guapos y los gauchos. El tango canción es una mediación operativa que conjuga algunos elementos de diversos entornos en un producto que alcanzará mayor difusión a través de la secularización de los temas de amor perdido, desencanto y arrabales lejanos; que conjugan lunfardismos, voseos y personajes constantes de míticas caudas que fungen como desolados agonistas de un pasado físico y cronológico. Si el tango primigenio cargaba en el aparente desenfado de su baile la añoranza, el tango canción pone en escena la variación explícita de la aflicción insiliar. Más aún, el personaje asume la condición de ausente de un contexto que le fue usurpado.

Como consecuencias de su auge parisino aparecen nuevos lugares en los que los sectores acomodados puede escuchar y bailar tangos: los cabarets. Asimismo, el desarrollo de nuevas formas expresivas, entre las que se halla el ya dicho tango canción y propicia también el surgimiento de poetas, cantores y compositores. En el caso de los cantores, es ineludible referirse a Carlos Gardel, quien arropó con la cauda de misterio muchos actos de su vida, incluyendo su 
lugar de origen, acto que en sí mismo fundamenta otra narrativa propia del desarraigo. La muerte prematura del Gardel en un accidente de avión, configura también parte de una mitología tanguera, quizá la primera que refiere a un personaje históricamente documentado, y del que surgen elementos de la narrativa que integran parte del panteón del género. Gardel es un expatriado uruguayo o francés, refieren las polémicas-que adquiere, por medio de la voz, la sonrisa y el sombrero ladeado, el peso de una identidad compleja y maleable a los designios de la nostalgia insiliar que proyecta los testimonios de su imagen.

Si los cantantes adquieren una dimensión propia de personajes del tango, también lo hacen los músicos; por decir, cuando el bandoneonista Vicente Greco establece hacia principios del s. XX el término orquesta típica, para referirse a las agrupaciones tangueras formadas por dos o más músicos, marca también un hito para la institucionalización del tango. A la Guardia Vieja le sucedió entonces una Guardia Nueva, con destacados músicos de transición que privilegiaron el estudio y la profecionalización a la intución. La amplicación del rango de instrumentos en las orquestas, a la vez que la búsqueda de una identidad sonora por cada agrupación, fueron pautas determinantes en la concreción del nuevo estilo. Con la institucionalización del género, aparece también una curiosidad intelectual que se dirige, tanto a inquirir los orígenes del fenómeno como a convocar mitologías arropadas en la trama de la complejidad tanguera (cfr. Anad 2011, pp.53-73).

Ahí están las disquisiciones sobre la historia del tango de Borges ([1930] 1989, pp.159-172) y, del mismo autor, para las Seis Cuerdas. En este libro el autor produce una melancólica simulación de las primeras milongas que se cantaban en los arrabales, ([1965] 2002, pp.191-221) homenaje cultista pleno en idealización sobre el lenguaje y los compadritos personajes que afirmaba haber contemplado en su niñez. Está también el Adan Buenosayres de Leopoldo Marechal, compleja alegoría que contiene la reconfiguración mítica de la ciudad en el edén distópico del personaje central, en cuya trama el tango opera un eje rector, por demás sutil (Marechal [1948] 1994).

Más, si el tango con su orígen popular fue capaz de inmiscuirse en el cultismo, también fue posible una comunicación inversa, de tal modo que la 
sonoridad metafórica se afianza también en las letras de los poetas populares. El tango Sur de Homero Manzi -estrenado en 1948, el mismo año en que se publica Adan Buenosayres- es la continuación de la expresión nostálgica presente en la añoranza de una cotidianidad disuelta: "Nostalgias de las cosas que han pasado, I arena que la vida se llevó / pesadumbre de barrios que han cambiado / y amargura del sueño que murió" (Manzi, 1948).

En 1943 se produjo en Argentina un golpe de estado cuyo resultado fue un dictadura que abarcó hasta 1946 y entre sus disposiciones se adaptó la censura de los lunfardismos en las letras del tango. Esta disposición tuvo, sin embargo, una connotación más profunda en tanto incluía también nociones consideradas inmorales y se privilegió el uso del tuteo en detrimento del voseo; este último como fenómeno lingústico frecuente en el litoral del Plata. La imposición de modelos enrarecidos conlleva también el descolocamiento de una realidad, y el subsecuente distanciamiento insiliar para con el contexto.

La década de 1950 es un periodo de transición y desgaste para el tango. Es el auge de compositores de avanzada (Osvaldo Pugliese, Horacio Salgán, Alberto Castillo, Anibal Troilo) pero también es un periodo de pérdidas, en tanto mueren los letristas Homero Manzi y Enrique Santos Discépolo. Estas ausencias, sumadas al inestable entorno político y al propio deterioro del género, propiciarian un decaimiento parcial del tango y sus modelos tradicionales. Es en este entorno, que el bandoneonista Astor Piazzolla forma, en 1958, el Octeto Buenos Aires; agrupación de avanzada que integra la guitarra eléctrica en sus filas. Piazzolla era nieto de inmigrantes italianos, nació en Mar del Plata en 1921 y había pasado la mayor parte de su infancia en Nueva York; lugar en donde recibió su primer bandoneón y donde también conocería a Carlos Gardel en 1933. En este periodo el jóven Piazzolla era musicalmente más cercano a Bach, al jazz y a otras mescolanzas musicales de Little Italy que al tango. Años después de este encuentro fortuito, el bandoneonista volvería a Argentina para integrarse a las filas de diversas orquestas típicas, hasta que un premio le granjeó la oportunidad de estudiar con Nadia Boulanger, quien le anima a proseguir una carrera más vinculada al tango, que hacia la música académica. 
En Piazzolla inciden múltiples vetas que adecuaron el desarrollo de el nuevo tango, según su propia conceptualización o de música contemporánea de la ciudad de Buenos Aires, apelativos de los que hacía uso según las circunstancias. De cualquier manera, Piazzolla contribuyó a redefinir musicalmente el género y aportó también elementos a la mitología tanguera, como las que se encuentran en la "operita" María de Buenos Aires, obra de un denso barroquismo literario y de una insoslayable belleza musical; en la que se narra la vida, muerte y resurrección de María, entidad mítica de un surrealista mundo tanguificado. La palabra de hecho es precisa: Piazzolla dice tanguificar fugas y parte de su esfuerzo conlleva a una reinterpretación del género, en tanto conviven en su obra la remembranza de los orígenes pendencieros, a la vez que la incorporación de contrapuntos, los modos de trasposición limitada o politonalidades.

El peculiar ánimo de Piazzolla otorga así una nueva dimensión al binomio del exilio en el tango. Su aprendizaje cosmopolita, la incursión en distintas formas musicales y su distanciamiento para con las formas clásicas del género le permiten reconocer algunas temáticas clásicas de la nostalgia, pero incorporar también, a través de colaboraciones y lecturas propias, elementos de una mediación contextual de las circunstancias políticas y sociales de las dictaduras. Esta circunstancia, como constante del género no solo en Piazzolla, fue vital para la difusión y revitalización del género; en tanto Argentina y Uruguay atravesaron procesos dictatoriales de 1976 a 1983 y de 1973 a 1984, respectivamente. Es en el ambiente de una melancolía fragmentada del retorno, que surge la revaloración de los hechos culturales vinculados con la identidad nacional y el conocimiento de dichas realidades en los países que los recibieron. Trataré esto después.

De cualquier modo, el tango no ha conjurado su avance, y conserva su privilegiada voz de testigo sobre nuevas narrativas dicotómicas de las particularidades del exilio y sus acepciones. Más aún, se reinventa y convive con formas y productos con los que en décadas anteriores ni siquiere se hubiera pensado: tango electrónico, tango rock, tango jazz y otros apelativos tendientes a los nominativos del crossover o hasta a la reapropiación de la misma identidad tanguificada por medio de una -así denominada- Guardia Jóven. 


\section{Gime, bandoneón ${ }^{19}$}

\subsection{El exilio de Gardel}

Tangos, el Exilio de Gardel (1985), es una película dirigida por el argentino Fernando "Pino" Solanas y que, junto con el film Sur marca el ingreso del director al campo de la ficción, así como su retorno a la escena cinematográfica argentina tras el exilio que sufrió desde 1975, como consecuencia del ascenso de la dictadura militar. En realidad, ambas películas resaltan expresiones complementarias del binomio exilio e insilio, pues si en El exilio... todo gira en torno de los expatriados del Río de la Plata en París; en Sur el tema central es el extrañamiento individual de una realidad soterrada ante un periodo de encierro carcelario. Si bien hubiera sido adecuado considerar ambas películas en esta sección, por motivos de practicidad y espacio solamente se abordará el primer film.

El exilio de Gardel se narra lo que concebimos como una exiliomaquia es decir, el esfuerzo por parte de los personajes para reconstruir en Paris, a través de una obra musical híbrida del tango, la comedia y el drama -denominada tanguedia- la reapropiación simbólica que trascienda su situación de expatriados. Para ello, en la tanguedia conviven arquetipos, evocaciones de identidades míticas y el humor amargo que surge del desconsuelo, todo ello destinado a integrar una cosmogonía revestida de vanguardia y nostalgia. Así, conviven en la misma cinta la figuración de los desterrados, la música de Astor Piazzolla y los recuerdos trashumantes de Enrique Santos Discépolo y Carlos Gardel.

La experiencia exiliar de Solanas nutre el proyecto, en tanto extiende su reconocimiento no solo los exiliados de un país, sino que acoge bajo el mismo sombraje la colaboración de uruguayos y argentinos, por igual, como personajes de la tanguedia. Todos ellos son, al fin y al cabo, una misma unidad constitutiva que se empecinan en contar, por medio de una particular historia su entorno: "Solo y sin un mango como en un suicidio, / solo tengo un tango pa' contar mi exilio" (“Solo" en Solanas, 1997 [1984]). Este verso de un tango que forma parte de la

\footnotetext{
${ }^{19}$ Es un fragmento del tango Nostalgias: "Gime bandoneón tu tango gris, / quizás a ti te hiera igual / algún amor sentimental..." en (Cristina Zetina, 1953, 176).
} 
musica del film, es ilustrativo del lenguaje atribuido al desarraigo y que permea todo el proyecto: la conjunción de suicidio y exilio no unicamente opera en la complementariedad sintáctica de la rima; sino también como significante metafórico de la situación: el exilio como un itinerario que dirige al abismo de la fragmentación individual, a la vez que constituye el sentido de hipotético de un "yo colectivo", de mayor peso que un "nosotros".

El exilio de Gardel, además de mostrar el avance del proceso creativo de la tanguedia, plantea también las problemáticas y desesperanzas cotidianas de los exiliados, escindidos generacionalmente entre los adultos, para quienes la conciencia de su desarraigo es mayor. Por su parte, los jóvenes intuyen un proceso de extrañamiento respecto a la realidad pasada de sus mayores, pero en quienes tampoco termina de condensarse la trama de una identidad. Serán así herederos de un pasado difuso, anclados en la pretérita ambigüedad de un patria ilusoria: "Somos hijos del exilio, dentro y fuera del país" (Hijos del exilio en Solanas, Tango, el exilio de Gardel, 1997 [1984]). El desenlace del film se haya sugerido desde el comienzo mismo: la nostalgia que señala siempre a la cotidianidad perdida, se resuelve con la recuperación del añorado ideal edénico, condensado en la representación del fantasma de Carlos Gardel cantando Volver, un tango de cuya significatividad que hablaré más adelante.

\subsection{El fuelle infinito}

El fuelle infinito es un cuento del escritor uruguayo Gabriel Schutz (Uruguay, 1973) que aparece en el libro de título homónimo y en el cual se compendian relatos de dos volúmenes previos del autor. La recopilación se compone de ficciones en las que la narración y urdimbre de los hechos cotidianos es teñida por un matiz de asombro y desconcierto. Todos ellos simulan un descolocamiento que no termina por dispersar la realidad, sino reiterarla y darle una dimensión de compleja simplicidad. El fuelle infinito narra los infortunios del aspirante a bandoneonista Anselmo Berruti, conductor de autobús; profesión inspirada en la del cantante Roberto Goyeneche (Schutz, comunicación personal, julio 19 de 2013). Este aspira, en su tiempo libre, a convertirse en parte de una orquesta de tango cuyos integrantes lo conocen con el oprobioso apelativo de "dedos de 
morcilla" ante su incapacidad de responder a los desafíos que los músicos malintenados disponen para él.

La narración pasa de una selección proléptica de acontecimientos cotidianos, hasta la morosidad cronológica suscrita en un hecho singular: el usualmente deficiente músico percibe cierto "olor" que le anuncia, junto al silencio de un extraño proscenio situado contiguo a un gran árbol, una circunstancia inusitada, no definible. Toma entonces el bandoneón y comienza a pulsar sus teclas y a mover su fuelle, de tal manera que los antes mordaces vecinos son partícipes de un improvisado acto que germina en perplejidad musical. No solo es una realidad mediata derivada de la circunstancia peculiar de una música que desplaza el principio de cotidianidad y propicia un hecho transitorio -hombres y mujeres bailan con un suave arrebato, sin conciencia plena del acto-, sino el posterior contexto de sucesos prodigiosos en los que todo el barrio y sus vecinos son capaces de recuperar una realidad pacífica. Ello en detrimento de Berruti, que sufre una particular catábasis como consecuencia del momento perdido -recurso tanguero del recuerdo al viejo pasado que se estima como inalcanzable en el presente del insilio de la geografía cronológica de la cual es despojado el sujeto.

El desenlace, -en el que Berruti intuye que el sortilegio que definió su vida no se encontraba en la imprevista fantasía que conoció, sino en su tosca cotidianidad- puede entenderse a la vez como un guiño y homenaje a "el gordo" Aníbal Troilo; bandoneonista fundamental en la historia del tango. En tanto el autor recupera una frase que, si bien ya se encontraba como epígrafe del cuento, en el contexto de la narración concluye con sentido pleno la historia: "Cuando toco estoy solo o con todos, que viene a ser lo mismo". Asimismo, el revire hacia Troilo permite recuperar ciertas características de la peculiar narrativa localista del músico, pues además de compositor de tangos clásicos, fue también autor de algunas glosas relativas a la propia identidad y a la conceptualización del insilio en su trama. Entre ellas se destaca el Nocturno a mi Barrio en el que incide: "Alguien dijo una vez / Que yo me fui de mi barrio, / ¿Cuándo? pero ¿cuándo? / ¡Si siempre estoy llegando! / Y si una vez me olvidé, / Las estrellas de la esquina de la casa de 
mi vieja / Titilando como si fueran manos amigas, / Me dijeron: gordo, gordo, quedáte aquí, / Quedáte aquí" (Troilo, 1968).

\subsection{Tangos}

El disco "Tangos" reproduce un concierto realizado en junio de 1995 en la sala Nezahualcóyotl de la ciudad de México en homenaje a Carlos Gardel a los 60 años de su fallecimiento y a Astor Piazzolla por los 15 años de su primera visita a México. Más allá de la apariencia del homenaje, hay una dirección encaminada a la reinterpretación del género. Por decir: los arreglos e instrumentaciones que se alejan en ocasiones de la estandarización tanguera, permiten distinguir segmentos de la intencionalidad del concierto. No se trata de una calca del género y menos aún del extremo opuesto: un juego de la industria cultura destinado a la producción y comercialización de un bien estereotipado ${ }^{20}$; sino de una lectura que le rinde estima al tango y busca aprehenderlo a un contexto especial. Igualmente, en la selección del repertorio conviven piezas que, si bien podrían definirse como clásicos del género, son en su mayoría posteriores a Gardel, -quien murió en 1935. El único tango de la selección que Gardel cantó -y cuya música es de su propia autoría- es Volver, pieza que se ubica junto con casi todas las restantes del disco dentro del tango canción.

Si bien, entre las primeras composiciones de dicho género y Volver hay diferencias sustanciales en la concreción del desarraigo, tales como que este tango no emplea lunfardismos destinados a la emulación de un contexto puesto que, tal como señala Horacio Salas (2008)., el objetivo del letrista Alfredo Le Pera:

(...) era trabajar en un castellano despojado de matices locales, que pudiera ser comprendido en todos los países hispanohablantes, dentro de un marco sentimental donde Buenos Aires sólo apareciera como una referencia a la lejanía, como el sitio del que alguna vez se ha partido (p.175).

\footnotetext{
${ }^{20}$ Un ejemplo típico de este fenómeno puede encontrarse en: Carlos Gardel, "El día que me quieras" en: (Segundo Romance [Luis Miguel Gallego Basteri], 1994). En dicha grabación se acomoda, junto a una arreglo más cercano al pop que al tango, el acompañamiento del bandoneón, a fin de legitimar el contexto sonoro de la grabación. Existe un video oficial de la grabación, en el cual se acentúa todavía más los estereotipos tangueros, a través de la presentación de elementos vinculados al auge europeo (parisino) del tango durante la primera mitad del s. XX. 
Así, la presencia del exilio es entonces, en la dimensión de Volver, una conceptualización sobre cierta realidad añorada; a la vez que la subversión del presente que evoca un edén perdido y en lo que asume un distanciamiento íntimo con la realidad actual: "Vivir, con el alma aferrada a un dulce recuerdo, que lloro otra vez" (León, 2006).

Es posible hacer un balance parecido a las cuatro piezas de Piazzolla incluidas en Tangos: tres de ellas son composiciones en las cuales aparece el reconocimiento explícito de espacios cotidianos de Buenos Aires: calles, monumentos, personajes e incluso la flora. Sin embargo, en Los pájaros perdidos hay también la confesión de una melancolía insiliar. En esta no se denota los lugares a los que refiere, situándolos más en un plano metafórico, inherente al propio título de la canción: "Soy solo un pájaro perdido / que vuelve desde el más allá, / a confundirse con un cielo / que nunca más podré recuperar" (León, 2006). Estos hechos contienen una trama inherente al despojo de un tiempo consuetudinario. El disco Tangos en la apariencia del homenaje -que no es sino una razón circunstancial- reconoce y reproduce dicha trama, quizá sin una conciencia plena que medie el acontecimiento de la separación y el enrarecimiento de una realidad trastornada. No es solo una expresión vívida del insilio que abarca la trama del tango, pero si un reflejo de la intencionalidad narrativa del fenómeno. Con el señalamiento de los hechos anteriores, se reitera que la dicotomía exilio/insilio se suscribe comúnmente a la definición de un estado de separación geográfica o a las secuelas de condiciones impuestas por un poder y que motivan el estado de desconocimiento transitorio para con la realidad. Sin embargo, la variedad de elementos mediadores que operan en la definición del tango, obligan a reiterar la necesidad de una amplitud en la consideración. Debido a la presencia de representaciones que emulan características del exilio interno sin que lo pretendan o fenómenos insospechados que despojan a la cotidianidad de su espacio: hay exilios sociales y económicos que surgen de la inconveniencia de modelos políticos y también insilios conllevados en la imposibilidad de acceder a las condiciones suscritas por las propias aspiraciones o por la censura de modelos y metáforas propias de una realidad lingüística. 
La pluralidad de los hechos debe corresponder a una especificidad operativa del término, por lo que la música y los mediadores que en ella operan resulta un adecuado crisol para describir las insospechadas formas que asume el desarraigo. Prueba de ello es el tango, en cuya cuna de arrabales plenos de desposeídos obtuvo el matiz de la melancolía y el recuerdo; a la vez que constituyó una cosmogonía particular que reproduce apariencias siempre reiterantes de la aspiración y el retorno. La definición menos compleja signa al tango como música. Pero sería más justa detallarla como: "música con memoria".

\section{Conclusiones}

De acuerdo con las perspectivas aquí expresadas, en el tango y sus latitudes -históricas y performativas- subyace una larga cauda de variables comunes. Estas se integran como narrativas con presencia en las variaciones con que el género se interpreta como música y a la vez es interpretado por distintas disciplinas en los proscenios del significado. Así el tango en la intención de una pertenencia cultural a países concretos, es un hecho de apariencia consumada pero que en las latitudes del desarraigo germina en un fenómeno difrásico que construye sentido en su desarrollo: sus complejos orígenes, nutridos por inmigraciones y desencuentros, lo delatan como tal. Así como las pequeñas variaciones que se suman en los destierros impuestos, en contextos más recientes. Parte de la esencia primordial que lo integra, se encuentra en el binomio exilio/insilio, como entidad fundamental desde sus orígenes mismos y presente en sus variaciones posteriores.

Esta investigación, surgió como un producto derivado de averiguaciones históricas sobre el tango y su presencia en México. Tras la frecuencia de ciertas variables en fuentes diversas, se vislumbró la posibilidad de señalar circunstancias comunes, más sutiles que las obvias diferencias presentes en las transformaciones geográficas del género. En ello radica parte de la riqueza que ofrece resituarlo por encima de consabidas disquisiciones que, si bien integran parte del corpus básico para aproximarse a los orígenes del hecho, retomarlas sin sentido crítico establecen un tropiezo al desarrollo de nuevas aproximaciones a los 
hechos. En tanto ya existen investigaciones del tango como hecho identitario, político, racional, literario y aún humorístico, es necesario ubicar descripciones similares en geografías más amplias que los extremos australes latinoamericanos o aún sugerir las aproximaciones que en otros espacios surjan como variables en dichos contextos. Ello con el fin de enriquecer nuevas posibilidades y no sólo aquellas consideraciones que denoten arranques con ecos atados a circunstancias más avecinadas a la tradición, y así responder con certeza a impugnaciones arraigadas en la prosaica descalificación. El tango no es una circunstancia absorta en un pasado inmóvil, es un presente que incesante se construye.

\section{Referencias Bibliográficas}

Amado, A. (2009). La Imagen Justa: Cine Argentino y Política, 1980-2007. Buenos Aires: Colihue.

Anad, G. (2011). Tango, transmodernidad y desencuentro. Nueva York: Peter Lagn Publishing.

Azzi, M. (et al.) (2002). Astor Piazzolla. Su vida y su música. Buenos Aires: El Ateneo.

Bajofondo Tango Club. (2007). Mar Dulce. Comp. Campodónico, Juan. et al.

Berger, Peter L., (et al.) (2006). La construcción social de la realidad. Buenos Aires: Amorrortu.

Borges, J.L. (1989 [1930]). «Historia del tango.» En Obras completas 1923-1949, de Jorge Luis Borges, 159-172. Sao Paulo, Brasil: EMECE.

Borges, J.L. (2002 [1965]). «Para las seis cuerdas.» En Obra poética II, de Jorge Luis Borges, 191-221. Madrid: Alianza Editorial.

Chase, A. (23 de octubre de 1995). Comentarios: Insilio", La Prensa Libre, p. 9.

Cristina Zetina, M. (et. al.). (1953). Reminiscencias del Plata del libro de oro del tango. México: Ediciones Olimpia.

Ferrer, H. (1970). El libro del tango. Historias e imágenes (Vol. I.). Buenos Aires: Ediciones Ossorio-Vargas.

Ferrer, H. (et al.) (1970). En persona. Comp. Piazzolla, Astor. 
Galeano, E. (1990). Memorias del fuego II. Las caras y las máscaras. España: Siglo XXI Editores.

Gallego, L.M. (2004). Segundo Romance. Comp. Carlos Gardel.

Garramuño, F. (2007). Modernidades primitivas. Tango, samba y nación. Buenos Aires: Fondo de Cultura Económica.

Gastón, E. (2008). Sociología del ballet. Fundamentos racionales y sociológicos de la danza. México, D.F.: Seminario de Cultura Mexicana.

Hennion A. (2002). La pasión musical. España: Paidos.

Horvath, R. (2006). Esos malditos tangos: apuntes para la otra historia. Buenos Aires: Biblos.

Kremer, G. (et al.) (1998). María de Buenos Aires. Comp. Astor Piazzolla.

León, E. (et. al). (2006) Tangos. Comp. Gardel, Carlos. et al.

Manzi, H. (1948) «Sur.» Todo Tango. Recuperado el 16 de julio de 2013 de http://www.todotango.com/Spanish/las obras/Tema.aspx?id=ck+Su3uU/+o=

Marechal, L (1994). Adan Buenosayres. Madrid: Castalia, [1948] 1994.

Mira Delli-Zotti, G. (2007). Explorando algunas dimensiones del exilio argentino en España.» En E. Rey (dir.). Memorias de la violencia en Uruguay y Argentina: golpes, dictaduras, exilios (1973-2006) (p.166). España: Universidad de Santiago de Compostela.

Nélida, M. (1993). Teatro Uruguayo Contemporáneo. Antología. Buenos Aires: Ediciones Colihue.

Pellegrino, A. «La migración internacional en América Latina.» Comisión Económica para América Latina y el Caribe. s/f. Recuperado el 26 de junio de 2013 de. http://www.eclac.cl/publicaciones/xml/1/34411/LCG.164 p6.pdf

Perelli, C. (1986). De mitos y memorias políticas: la represión, el miedo y después. Montevideo: Ediciones de la Banda Oriental.

Pérez, E (2012). Mística del lenguaje y mística del exilio. En B. Caballero (coord.). Exilio e identidad en el mundo hispánico: reflexiones y representaciones (pp. 86100). Biblioteca Virtual Cervantes. Recuperado el 10 de julio de 2013 de http://www.cervantesvirtual.com/descargaPdf/exilio-e-identidad-en-el-mundohispanico-reflexiones-y-representaciones/ 
Piazzolla, A. (et al.) (1997) Tango, el exilio de Gardel [sic]. Sur. El Viaje.Comp. Piazzolla, Astor et al.

Sabato, Ernesto (direc.) (1997). Tango. Buenos Aires: Losada.

Salas, H. (2008). El tango. México, D.F.: Laberinto Ediciones.

Sareli, J.(1974). El libro mayor del tango. México: Diana.

Savigliano, M. (2013). Tango and the Political Economy of Passion, Lexington, West View Press.

Schutz, G. (2006). El fuelle infinito. Ciudad Universitaria, México D.F.: Textos de Difusión Cultural, UNAM.

Solanas, F. (1984). "Pino". Tango, el exilio de Gardel. Comp. Piazzolla, Astor 1997 [1984].

Sur. Dirigido por Fernando "Pino" Solanas. 1988.

Tangos: el exilio de Gardel. Dirigido por Fernando "Pino" Solanas. 1985.

Troilo, Aníbal. et al. Nocturno a mi barrio. Comp. Troilo, Aníbal. 1968. 